\title{
RESEARCH
}

Open Access

\section{Biochemical characterization of micropropagated Ceratonia siliqua L. under effect of growth regulators and light quality}

\author{
Sawsan S. Sayed', A. M. M. Gabr², Mona A. Amin³ and Lobna S. Taha ${ }^{4^{*}}$
}

\begin{abstract}
Background: Carob (Ceratonia siliqua L.) is one of the important crops in terms of nutritional and medicinal value in the countries of Western Asia and North Africa. Despite the fact that some countries have used Carob in traditional medicines, the modern food industry began to discover the great potential of this plant which differentiates with antioxidant capacity as well as other important medicinal activities. Some of very few studies that have been reported on this important plant were published.

Methodology: In the present study, micropropagation behavior and biochemical constituents of Ceratonia siliqua L. cultured on MS medium supplemented with different types and concentrations of cytokinins (0.0, 0.5, 1.0, or 1.5 mg/l BA, Kin, or TDZ and 0.2 mg/l NAA) under various light qualities ((white, green, blue, red, and yellow) were examined.

Results: MS culture medium supplemented with BA produced the highest shootlets number/explants. For light quality, the data showed that green light increased shootlet number/explants, fresh and dry weights. However, yellow light increased shootlet length and leaves number and also caused significant increase in total phenols, flavonoids, and antioxidant capacity (DPPH) as compared to other lights. HPLC analysis showed that yellow light caused the highest accumulation of total phenolic and catechin that were the highest accumulated compounds $(509 \mathrm{\mu g} / \mathrm{ml})$ followed by that were accumulated under green light $(412.68 \mu \mathrm{g} / \mathrm{ml})$. Shootlets grown under white light (control) gave the highest accumulation of p-coumaric acid, rosmarinic acid, and cinnamic acid. Shootlets grown under blue light gave the highest accumulation of gentisic acid and syringic acid. Red light caused the highest accumulation of vanillic acid. However, white light accumulated the highest amount of flavonoid compounds comparing with other light qualities.

Conclusion: This study had reached to optimize a suitable micropropagation protocol of Ceratonia siliqua L. and characterization of biochemical constituents that can be beneficial for increasing its medical value which will help in food industries for commercial purposes.
\end{abstract}

Keywords: Ceratonia siliqua L., Cytokinins, Light, In vitro growth, Biochemical

\footnotetext{
* Correspondence: lobnasalah82@yahoo.com

${ }^{4}$ Ornamental Plant and Woody Trees Department, Agricultural and Biological

Research Division, National Research Centre (NRC), Cairo, Egypt

Full list of author information is available at the end of the article
} 


\section{Background}

Carob tree (Ceration siliqua L.) belongs to family Fabaceae. It is widely cultivated for its edible pod, and as ornamental tree in gardens (Girolamo and Laura 2002). It is used in reforestation action and its cultivation in modern orchards is being undertaken to value marginal lands and substitute for drought sensitive species (Sidina et al. 2009). The economic importance of this species comes from its industrial utilization. Pods and seeds of carob are used as raw material in food, pharmaceutical, and cosmetic industries (Barracosa et al. 2007). Propagation of Ceratonia siliqua by seeds does not ensure either the sex or the genetic characteristics of the ecotype (Barracosa et al. 2007). Using propagation by cutting has failed because rooting is difficult (Lee et al. 1997). So, using in vitro culture allows an alternate option for carob propagation (Romano et al. 2002), and is considered as a technique for the preservation of plant genetic material, the grown plant breeding program, and the fast production of large quantities of propagation materials (Mitrakos 1987). In this respect, many researches of Ceratonia siliqua micropropagation using various explants are available (Thomas and Metha 1983 and Romano et al. 2002). Using type and concentration of cytokinins were the most important factors affecting on shoot multiplication and the best multiple shoot response was obtained with using MS medium (Romano et al. 2002). Light quality was effective by modulated photoreceptors on shoot elongation and lateral branching through changing the concentration of plant hormones (Muir and Zhu 1983; Smith 1982). Plants have evolved a plethora of signal-transducing photoreceptors that regulate their growth and development in relation to the presence, amounts, direction, duration, and quality of light (Smith 1994; Quail 2002). Plant responses do not depend only on the absence or presence of light but also on the variations in light quality (Pedroso et al. 2017). Light quality has important effects on plant growth and development, especially for photosynthesis and photo morphogenesis, the two process that, through signals received by the photoreceptors, regulate plant growth, differentiation, and metabolism (Guo et al. 2007). Plant growth can be affected by endogenous hormone levels interactions with light quality. In this respect, Ou Yang et al. (2015) revealed that red and blue lights are associated with plant growth, development, and phytohormone metabolism. In addition, they reported that blue light promotes IAA accumulation and phenylpropanoid biosynthesis. In contrast, red light affects stem growth by regulating biosynthesis of GAs.

These experiments aimed to establish a micropropagation protocol that can be used in further studies for mass production of shootlets and secondary metabolites from Ceratonia siliqua L. plant.

\section{Materials and methods}

This investigation was carried out during the years 2018 and 2019 at Tissue Culture and Germplasm Conservation Research Laboratory, Horticulture Research Institute, Agriculture Research Center (ARC) and Tissue Culture Technique lab., Central laboratories, Department of Ornamental Plants and Woody Trees, National Research Center (NRC), Egypt on Ceratonia siliqua L. to optimize a micropropagation protocol and enhance biochemical synthesis.

\section{Plant materials}

Nodal segments of carob were excised from female juvenile suckers which were grown at Horticulture institute farm in March 2018. The explants were sterilized by $0.1 \%$ mercuric chloride (MC) for $10 \mathrm{~min}$ and cultured on free MS (Murashige and Skoog 1962) medium for 4 weeks (all explants survived and free contaminated).

\section{Culture medium}

Cuttings obtained from in vitro propagated shootlets at $2.0 \mathrm{~cm}$ long were excised and individually placed on 250 $\mathrm{ml} /$ jar containing $25 \mathrm{ml}$ of MS basal medium supplemented with $25 \mathrm{~g} / \mathrm{l}$ sucrose and solidified with agar $(7 \mathrm{~g} /$ 1). The $\mathrm{pH}$ of medium was adjusted to $5.7 \pm 0.1$ with HCL $0.1 \mathrm{~N}$ or $\mathrm{NaOH} 0.1 \mathrm{~N}$ before sterilization by autoclaving at $121{ }^{\circ} \mathrm{C}$ for $30 \mathrm{~min}$. Growth regulators: 6Benzylaminopurine (BAP), Thidizeron (TDZ), Kinetin (Kin), and naphthalene acetic acid (NAA) were added to the culture medium according to the experimental stage as follows:

The explants that survived and free contaminated were cultured on full MS medium supplemented with different types of cytokinins (BA, Kin, or TDZ) at various concentrations $(0.0,0.5,1.0$, or $1.5 \mathrm{mg} / \mathrm{l})$ in combination with $0.2 \mathrm{mg} / \mathrm{l} \mathrm{NAA}$. After the third subculture, shootlet number/explants, shootlet length $(\mathrm{cm})$, and leaves number/shootlet were recorded.

\section{Incubation conditions}

Cultures were incubated under 16:8 h photoperiod of cool-white light at 1250 lux during all stages.

The best multiplication medium $(0.5 \mathrm{mg} / \mathrm{l} \mathrm{BA}+0.2$ NAA) was used for testing the proliferation ability of in vitro cultures under different light qualities (white, green, blue, red, and yellow) using LED light source.

The shootlet number/explants, shootlet length $(\mathrm{cm})$, leaves number/shootlet, fresh and dry weights (g), and the estimation of biochemical analysis were recorded after 1 month.

\section{Analytical scheme}

Spectrophotometer analysis for total phenolic content (TP), total flavonoid content (TF), and free radical 
scavenging activity were performed on jenway (6715, UK). For evaluation of TP, TF, and free radical scavenging activity of in vitro shoots, the samples were subjected to extraction according to the protocol described by Gabr et al. (2016). Total phenolic content was performed using Folin-Ciocalteu reagent according to the method reported by Velioglu et al. (1998) and was calculated using the following and expressed in mg gallic acid/I.

Total phenolic production $(\mathrm{mg} / \mathrm{l})=\mathrm{DW}(\mathrm{g} / \mathrm{l}) \times$ total phenolic content $(\mathrm{mg} / \mathrm{g})$.

Total flavonoid content was determined using aluminum chloride (ALCL colorimetric method reported by Chang et al. 2002) and expressed in mg quercetin/I.

For antioxidant activity determination, 2,2-diphenyl-1picrylhydrazyl (DPPH) was used as described by Gabr et al. (2016).

HPLC analysis for phenolic and flavonoids was performed on an Agilent 1100 liquid chromatography with Zorbax SB-C18 Column. Samples $(20 \mu \mathrm{l})$ were injected and analyzed at flow rate of $0.4 \mathrm{ml} \mathrm{min}$ at $35{ }^{\circ} \mathrm{C}$. A gradient programme was used with $1 \%(\mathrm{~V} / \mathrm{V})$ aqueous phosphoric acid (eluent A) and 40\% (V/V) aqueous acetonitrile (eluent B). The eluent was monitored at 254, 290 , and $330 \mathrm{~mm}$. The identification and quantification of phenolic acids were done by comparing retention time and area of the peaks in the extracts against that of the standard compounds. All standards were purchased from Sigma-Aldrich.

\section{Statistical analysis}

In all treatments, 25 explants in five replicates were used. The lay-out of the experiment was designed in complete randomized design and test least significant difference (LSD) at $p \leq 0.05$ was used for comparison among means according to Steel and Torrie (1980).

\section{Results}

Effect of different cytokinin types and concentrations on shooting behavior

Data in Table 1 clearly show the effect of fortified of MS medium with cytokinins different type (BA, Kin, or TDZ) at various concentrations $(0.0,0.5,1.0$, or $1.5 \mathrm{mg} /$ l) with $0.2 \mathrm{mg} / \mathrm{l} \mathrm{NAA}$ on behavior of shooting. The data clarified that explants cultured on MS medium supplemented with BA produced maximum shootlet number/ explants at three concentrations $(0.5,1.0$, or $1.5 \mathrm{mg} / \mathrm{l})$ which gave $(2.75,2.79$, or 2.82 shootlet/explant, respectively). On the other hand, MS culture medium free of hormones reduced shootlet number/explants (2.20 shootlet) and led to the longest shootlets $(2.35 \mathrm{~cm})$. MS medium supplemented with $1.5 \mathrm{mg} / \mathrm{l}$ of TDZ increased leaves number/shootlet (3.60 leaf/shootlet).
Table 1 Effect of different types of cytokinin at different concentrations on shooting behavior of Ceratonia siliqua $\mathrm{L}$

\begin{tabular}{llll}
\hline Character & $\begin{array}{l}\text { Shootlets } \\
\text { number/ } \\
\text { explant }\end{array}$ & $\begin{array}{l}\text { Shootlet } \\
\text { length } \\
(\mathrm{cm})\end{array}$ & $\begin{array}{l}\text { Leaves } \\
\text { number/ } \\
\text { shootlet }\end{array}$ \\
\hline Control (MS free of hormones) & 2.20 & 2.35 & 3.20 \\
$0.5 \mathrm{BA}+0.2 \mathrm{NAA}$ & 2.75 & 2.10 & 3.40 \\
$1.0 \mathrm{BA}+0.2 \mathrm{NAA}$ & 2.79 & 1.90 & 3.20 \\
$1.5 \mathrm{BA}+0.2 \mathrm{NAA}$ & 2.82 & 1.90 & 2.80 \\
$0.5 \mathrm{kin}+0.2 \mathrm{NAA}$ & 2.30 & 2.20 & 3.20 \\
$1.0 \mathrm{kin}+0.2 \mathrm{NAA}$ & 2.45 & 1.90 & 2.80 \\
$1.5 \mathrm{kin}+0.2 \mathrm{NAA}$ & 2.65 & 2.20 & 3.60 \\
$0.5 \mathrm{TDZ}+0.2 \mathrm{NAA}$ & 2.50 & 2.10 & 2.60 \\
$1.0 \mathrm{TDZ}+0.2 \mathrm{NAA}$ & 2.60 & 1.80 & 2.40 \\
$1.5 \mathrm{TDZ}+0.2 \mathrm{NAA}$ & 2.55 & 1.80 & 2.40 \\
LSD at 5\% & 0.43 & 0.48 & 0.81 \\
\hline
\end{tabular}

Effect of light quality on in vitro growth behavior

Data in Table 2 and Fig. 1 indicated that incubation of cultures under different light qualities showed variations in in vitro growth of shootlets as well as fresh and dry weights of shootlets. Cultures that were incubated under green light produced highest values of shootlet number (3.34) and fresh and dry weights (5.04 and $1.83 \mathrm{~g}$, respectively). On the other hand, cultures that incubated under yellow light produced longest shootlet and highest leaves number $(3.82 \mathrm{~cm}$ and 5.02 leaf/shooltlet).

\section{Total phenol and total Flavonoids content}

Significant variances in total phenol content profile were shown by in vitro Ceratonia siliqua shootlets grown under different light spectrum. Plantlets grown under yellow light present the maximum level $(27.59 \mathrm{mg} / \mathrm{ml})$ (Fig. 2). Shootlets grown under yellow light showed the highest total phenol content $(25.03 \mathrm{mg} / \mathrm{ml})$, followed by green and red $(22.58$ and $20.49 \mathrm{mg} / \mathrm{ml})$, respectively. While the lowest total phenol content level was shown with blue lights $(16.78 \mathrm{mg} / \mathrm{ml})$. Total flavonoids content showed (Fig. 3) the same as total phenol content, shootlets grown under yellow light presented the maximum level of total flavonoids content $(826.069 \mu \mathrm{g} / \mathrm{g}$ DW). Red light accumulated high level of total flavonoids content compared with blue or green lights $(626.69,508.44$, and $421.16 \mu \mathrm{g} / \mathrm{g}$ DW, respectively).

\section{Antioxidant capacity DPPH}

Shootlets grown under yellow light gave the highest antioxidant capacity (87.37\%) compared with other light qualities as well as control (white light). Shootlets grown under red light gave the lowest antioxidant capacity $(80.316 \%)$. Interestingly, a positive correlation was found between total phenol, total flavonoids, and antioxidant 
Table 2 Effect of light quality on shooting behavior of Cerationia siliqua L

\begin{tabular}{llllll}
\hline Light quality & Shootlets number/explant & Shootlet length $(\mathrm{cm})$ & Leaves number/shootlet & Shoot fresh weight $(\mathrm{g})$ & Shoot dry weight $(\mathrm{g})$ \\
\hline White & 2.74 & 2.10 & 3.40 & 5.04 & 1.20 \\
Green & 3.340 & 3.04 & 3.54 & 6.63 & 1.83 \\
Blue & 2.98 & 2.70 & 3.68 & 5.97 & 1.42 \\
Red & 3.04 & 2.96 & 3.60 & 6.48 & 1.63 \\
Yellow & 2.52 & 3.82 & 5.02 & 5.81 & 1.35 \\
LSD at 5\% & 0.70 & 1.07 & 0.87 & 0.88 & 0.22 \\
\hline
\end{tabular}

capacity. The different spectrum of lights induced a change in antioxidant activity in similar mode to that of total phenol, total flavonoids content, which signify that most of the phenolic and flavonoids compounds, in extract act as antioxidants.

\section{Effect of light quality on phenolic and flavonoids compounds HPLC analysis}

HPLC was used to identify 13 phenolic acids and seven flavonoids under the impact of five different light qualities (Table 3). The obtained results showed highly different amounts of the different identified phenolic acids. Yellow light promoted the accumulation of gallic acid, catechin, chlorogenic acid, and sinapic acid with high accumulation of total phenolic acids. While, white light (control) accumulated a high amounts of pcoumaric acid, rosmarinic acid, and cinnamic acid.

Results of flavonoids as shown in Table 4 showed that the highest value of rutin accumulated in shootlets subjected to blue light $(22.16 \mu \mathrm{g} / \mathrm{ml})$. White light improved the accumulation of all other flavonoids than other spectrum of light.

\section{Discussion}

The present data in Table 1 were in agreement of those found by Saïdi et al. (2016) on carob and Sawsan and
Zienab (2014) on Cephalotaxus Harrington; they reported that BAP $(0.5 \mathrm{mg} / \mathrm{l})$ with NAA $(0.1 \mathrm{mg} / \mathrm{l})$ stimulated better stem formation and those growth.

Data in Table 2 were confirmed by early results found by many reports (Gabryszewska and Rudnicki 1995; Bach and Malik 1999; Bach et al. 2000; Bach and Swiderski 2000; Witomska and Koszewska 2002) who mentioned that light quality significantly affected dry weight, plantlet height, and number of leaves. Red light significantly enhanced adventitious bud formation and shoot elongation in petunia and Gerbera, while blue light increased the number of adventitious buds and fresh weight of shoots on Freesia, Hyacinthus and Cyclamen.

Concerning results of total phenol and total flavonoids content (Figs. 2 and 3), Ardeleana et al. (2018) found that yellow light produced high levels of total phenol and total flavonoids in in vitro seedlings of Ocimum basilicum L. cultivar Aromat de Buzau than red or white lights. Our results indicated that red light is more effective than blue in production of total phenol content as well as total flavonoids content. Similarly, red light enhanced phenolic content in leaf of lettuce and total flavonoid content in Rehmannia glutinosa (Manivannan et al. 2015; Li et al. 2013). On the other hand, Bach et al. (2015) reported that red and blue light treatments did

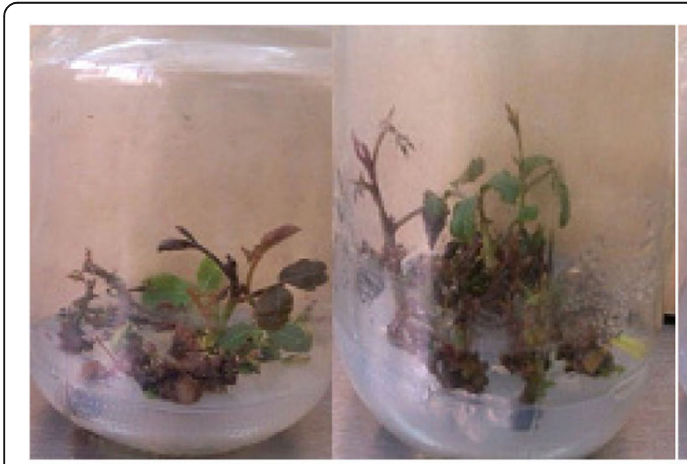

A: White
B: Green

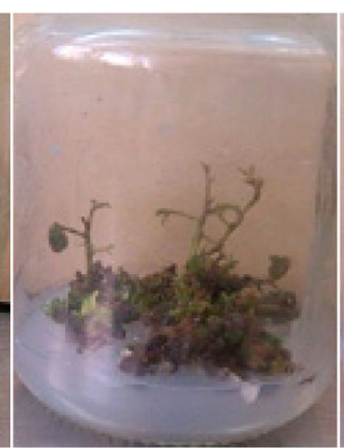

C: Blue

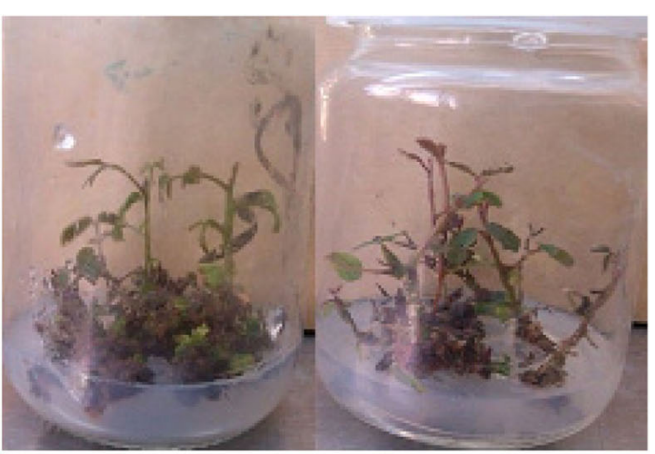

D: Red
E: yellow

Fig. 1 Effect of light (a white, $\mathbf{b}$ green, $\mathbf{c}$ blue, $\mathbf{d}$ red, and e yellow) on in vitro growth behavior of Ceratonia siliqua L. cultured on MS medium supplemented with $0.5 \mathrm{mg} / \mathrm{BA}+0.2 \mathrm{NAA}$ 


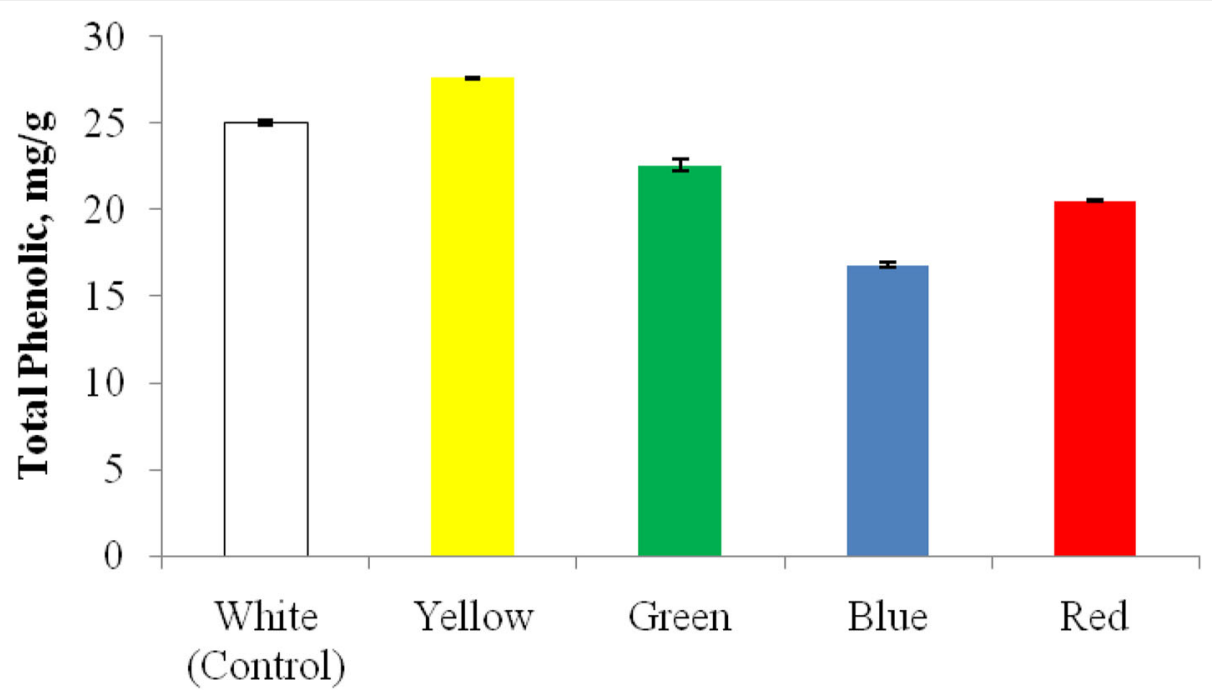

Fig. 2 Total phenolic contents (mg/g DW) under different lights qualities represent means \pm slandered errors from triplicates

not induce any changes in the content of total phenolics between the studied cultivar sachenalia (Ronina and Rupert). Younas et al. (2018) reported that deviations in total phenolic and flavonoid contents reveal that light quality affect different plant species variably. Shiga et al. (2009) reported that white light enhanced phenolic content and antioxidant activity in Ocimumba silicum.

The results in Table 3 are in agreement with LealCosta et al. (2015). They found that yellow light improved the production of phenolic compounds in Phyllanthus tenellus grown in vitro. Likewise, Shiga et al. (2009) reported that white light enhanced accumulation of chicoric acid, romarinic acid, and caffeic acid in Ocimumba silicum. On the other hand, Bach et al. (2015) found that total production of phenolic compounds in Lanchenalia "Ronina" and "Rupert" in vitro cultures subjected to white and blue light varied from 1.1 to $2.0 \mathrm{mg} /$ g dry weight and it was higher than lachenalia exposed to red light $(0.5 \mathrm{mg} / \mathrm{g}$ dry weight). Szopa and Ekiert (2016) investigated the influenced of lighting conditions (far-red, red, blue, white, and darkness) on lignin and phenolic acids accumulation. They found that blue light was found to be the most effective lighting to the production of both groups of compounds. Their total amounts reached the maximum values of $376.41 \mathrm{mg} / 100$ g dry weight and $46.57 \mathrm{mg} / 100 \mathrm{~g}$ dry weight, and were correspondingly 1.31 and 1.37 times greater than under white light. The amounts of individual compounds from

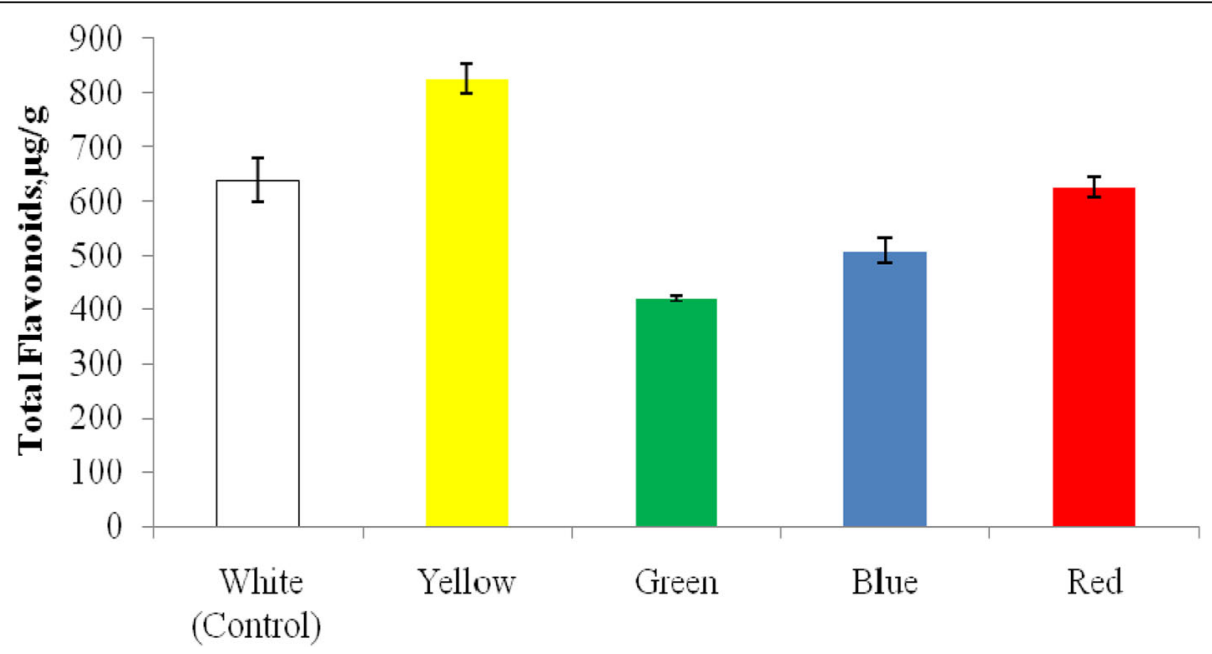

Fig. 3 DPPH free radical scavenging (\%) under different light qualities. Values presented means \pm standard error from replicates 
Table 3 Comparison of phenolic acids under the five different light qualities on Ceratonia siliqua L

\begin{tabular}{llllll}
\hline Compounds $(\mu \mathrm{g} / \mathrm{ml})$ & White (control) & Yellow & Green & Blue & Red \\
\hline Gallic acid & 6.18 & 6.30 & 4.41 & 5.56 & 4.46 \\
Protocatechuic acid & 2.76 & 2.50 & 2.78 & 2.63 & 1.97 \\
$p$-Hydroxybenzoic acid & 0.00 & 1.79 & 3.39 & 3.16 & 2.20 \\
Gentisic acid & 0.20 & 0.15 & 0.69 & 1.08 & 0.58 \\
Catechin & 323.03 & 509.00 & 412.68 & 265.44 & 267.12 \\
Chlorogenic acid & 0.00 & 0.17 & 0.00 & 0.10 & 0.14 \\
Syringic acid & 2.94 & 1.29 & 2.72 & 6.81 & 2.14 \\
Vanillic acid & 1.48 & 1.41 & 1.62 & 1.69 & 1.79 \\
Ferulic acid & 0.23 & 0.19 & 0.26 & 0.17 & 0.23 \\
Sinapic acid & 0.24 & 0.28 & 0.26 & 0.23 & 0.27 \\
p-Coumaric acid & 3.13 & 0.65 & 0.54 & 0.99 & 1.00 \\
Rosmarinic acid & 0.46 & 0.23 & 0.19 & 0.20 & 0.29 \\
Cinnamic acid & 0.14 & 0.02 & 0.05 & 0.06 & 0.11 \\
Total & 340.80 & 523.98 & 429.58 & 288.10 & 282.30 \\
\hline
\end{tabular}

the tested groups increased from 1.51 to 3.38 times (lignin), and from 1.74 to 2.72 times ( phenolic acids), depending on the lighting condition.

The results in Table 4 are in harmony with Pedroso et al. (2017) when studied the impact of five different lights on rutin accumulation in in vitro cultivated Hyptismarrubioides. They demonstrated the blue and white lights promoted the greatest rutin accumulation (0.30 and $0.31 \mathrm{mg} \mathrm{g}^{-1}$ of dry weight) after 30 days of irradiation. In line with these results, Thwe et al. (2014) reported that irradiation with blue light increased polyphenol content in lettuce and induced the production of rutin and cyaniding 3-0-rutinoside in Fagopyrum tataricum.

\section{Conclusion}

Investigation of growth regulators and light quality on in vitro culture of Ceratonia siliqua revealed that adding

Table 4 Comparison of flavonoid under the five different light qualities on Ceratonia siliqua L

\begin{tabular}{llllll}
\hline Compounds $(\mu \mathrm{g} / \mathrm{ml})$ & White (control) & Yellow & Green & Blue & Red \\
\hline Rutin & 21.62 & 13.04 & 9.65 & 22.16 & 8.21 \\
Apigenin-7-glucoside & 3.65 & 2.32 & 2.07 & 3.55 & 1.56 \\
Myricetin & 0.34 & 0.20 & 0.22 & 0.22 & 0.25 \\
Quercetin & 0.38 & 0.09 & 0.08 & 0.10 & 0.11 \\
Apigenin & 0.43 & 0.24 & 0.28 & 0.24 & 0.25 \\
Kaempferol & 0.48 & 0.00 & 0.09 & 0.08 & 0.00 \\
Chrysin & 0.43 & 0.00 & 0.1 & 0.00 & 0.00 \\
Total & 27.33 & 15.89 & 12.48 & 26.36 & 10.39 \\
\hline
\end{tabular}

$0.5 \mathrm{mg} / \mathrm{l}$ BA with $0.2 \mathrm{mg} / \mathrm{l} \mathrm{NAA}$ to $\mathrm{MS}$ medium produced large shootlet number/explant. For light quality, green light increased shootlet number/explant, fresh and dry weights. Besides that, yellow light increased total phenol, total flavonoids, and antioxidant capacity (DPPH) and increased accumulation of total phenolic acid and catechin.

\section{Acknowledgment \\ The authors are greatly thankful to National Research Center, 33 El Bohouth \\ St. (El Tahrir St.) Doki-Giza-Egypt and Horticulture Research Institute 9 El-}

Gmaa St. Giza Egypt for supporting this work.

\section{Authors' contributions}

SS. S, MA. A, and LST performed the in vitro experiment, analyzed the data. AMM Gabr performed the analysis for biochemical study. All authors contributed in writing, reviewing the paper, and approved the final manuscript.

\section{Authors' information}

Prof. Dr Sawsan S. Syed Researcher Professor at Ornamental DepHorti. Res. Ins., Agric .Res. Centre,Giza, Egypt

Prof. Dr. Ahmed M M Gabr Researcher Professor at Plant Biotechnology Dept., Genetic Enginerring and Biotechnology Division, National Research Centre (NRC), Egypt

Dr. Mona Ahmed Amin Researcher at Woody Trees Dep. Horti. Res. Ins., Agric. Res. Center, Giza, Egypt.

Prof. Dr. Lobna Salah Taha Researcher Professor at Department of Ornamental plants and Woody trees, Agricultural and Biological Res. Division, National Research Centre (NRC), P.O. Box 12622 Dokki, Giza, Egypt.

\section{Funding}

This work was supported and funded by the National Research Centre. Project No. (11030152) under the title "Propagation of economic importance ornamental and woody plants using new applications." during 2016/2019.

\section{Availability of data and materials}

The datasets generated and/or analyzed during the current study are included in this published.

Ethics approval and consent to participate

Not applicable.

\section{Consent for publication}

Not applicable.

\section{Competing interests}

The authors declare that they have no competing interests.

\section{Author details}

'Ornamental Department, Horticultural Research Institute, Agricultural Research Centre, Giza, Egypt. ${ }^{2}$ Plant Biotechnology Department, Genetic Engineering and Biotechnology Division, National Research Centre (NRC), Giza, Egypt. ${ }^{3}$ Woody Trees Department, Horticultural Research Institute, Agricultural Research Center, Giza, Egypt. ${ }^{4}$ Ornamental Plant and Woody Trees Department, Agricultural and Biological Research Division, National Research Centre (NRC), Cairo, Egypt.

Received: 1 November 2019 Accepted: 4 February 2020

Published online: 14 February 2020

\section{References}

Ardeleana M, Ardeleana A, Don I, Lobiuc A, Burducea M (2018) Effect of led lighting on growth and phenolic content on in vitro seedlings of ocimumbasilicum I. cultivar, "Aromat de Buzau",Food and Environment Safety. XVII (1): $66-73$

Bach A, Kapczynska A, Dziurka K, Dziurka M (2015) Phenolic compounds and carbohydrates in relation to bulb formation in Lachenalia 'Ronina' and 
'Rupert' in vitro cultures under different light in environments. Scientia Horticulturae. 188:23-29

Bach A and Malik M (1999) Effect of light quality on somatic embryogenesis of Cyclamen persicum Mill. 'Medium'. In:Schwenkel HG [ed.], Reproduction of Cyclamen persicum Mill. through somatic embryogenesis using suspension culture systems, 27-36. Directorate General for Research of European Commission, COST Action 822

Bach A, Malik M, Ptak A, Kędra M (2000) Effect of light quality on morphogenesis of bulbous ornamental microplant. Acta Hort. 53:173-180

Bach A, Świderski A (2000) The effect of light quality on organogenesis of Hyacinthus orientalis L in vitro. Acta Biologica Cracoviensia Series Botanica42/ 1: $115-120$

Barracosa P, Osorio J, Cravador A (2007) Evaluation of fruit and seed diversity and characterization of carob (Ceratonia siliqua L.) cultivars in Algarve region. Scientia Horticulturae. 114:250-257

Chang CC, Yang MH, Wen HM, Chern JC (2002) Estimation of total flavonoid content in propolis by two complementary colorimetric methods. Journal of Food and Drug Analysis. 10:178-182

Gabr AM, Hoda B, Mabrok KZ, Ghanem MB, Iryna S (2016) Lignin accumulation in callus and Agrobacterium rhizogenes-mediated hairy root cultures of flax (Linumusita tissimum). Plant Cell Tiss Organ Cult. 126(2):255-267

Gabryszewska E, Rudnicki R (1995) The influence of light quality on the shoot proliferation and rooting of Gerbera jamesonii in vitro. Acta Agrobotanica 48(2):105-111

Girolamo R, Laura D (2002) Evaluation and preservation of genetic resources of carob (Ceratonia siliquaL.) in southern of Italy for pharmaceutical use. Breed. Res.Aromat. Med. Plants. 9:367-372

Guo B, Liu YG, Yan Q, Liu CZ (2007) Spectral composition of irradiation regulates the cell growth and flavonoids biosynthesis in callus cultures of Saussurea medusa Maxim. Plant Growth Regul. 52:259-263

Leal-Costa MV, Tavares ES, Kuster RM, Lage CLS (2015) Light spectra affect themorphoanatomical and chemical features of clonal Phyllanthus tenellus Roxb. grown in vitro. Journal of Medicinal Plants Research. 9:111-121

Lee CL, Paul JL, Hackett WP (1997) Promoting of rooting in stem cuttings of several ornamental plants by pretreatment with acid or base. Hort. Science. 12:41-42

Li H, Tang C, Xu Z (2013) The effects of different light qualities on rapeseed (Brassica napusL.) plantlet growth and morphogenesis in vitro. Scientia Horticulturae. 150:117-124

Manivannan A, Soundararajan P, Halimah N, Ko CH, Jeong BR (2015) Blue LED light enhances growth, phytochemical contents, and antioxidant enzyme activities of Rehmannia glutinosa cultured in vitro. Horticulture, Environment and Biotechnology. 56:105-113

Mitrakos K (1987) The botany of Ceratonia. In Fito, P. and Milet, A. (eds). Proceeding of the III International Carob Symposium. Generalitat Valenciana, ConselleriaD'Agriculture I Pesca, September-October 1986, Valencia, Spain. 209-218

Muir RM, Zhu L (1983) Effects of light in the control of growth by auxin and its inhibitor (s) in the sunflower. Physiol. Plant, 57: 407-410. Netherlands, pp. $377-416$

Murashige T, Skoog F (1962) A revised medium for rapid growth and bioassays with tobacco tissue culture. Physiol. Plant. 15:473-497

OuYang F, Mao JF, Wang J, Zhang S, Li Y (2015) Transcription analysis reveals that red and blue light regulate growth and phytohormone metabolism in Norway spruce [Piceaabies (L.) Karst]. DOI: https://doi.org/10.1371/ journal. pone. 0127896

Pedroso R C N, Pedrosoa, Núbia Angelica A, Branquinhoa, Alessandra C.B.A.M. Haraa, Alan Carlos Costaa, Fabiano Guimarães Silvaa, Leticia P. Pimenta b, Marcio Luiz A. Silva, Wilson Roberto Cunha, Patricia M Pauletti, Ana Helena Januario (2017) Impact of light quality on flavonoid production and growth of Hyptismar rubioides seedlings cultivated in vitro. Revista Brasileira de Farmacognosia 27: 466-470

Quail PH (2002) Photosensory perception and signal ling in plant cells: new paradigms Curr. Opin. Cell Biol. 14:180-188

Romano A, Barros S, Martins-Loução MA (2002) Micropropagation of the Mediterranean tree Ceratonia siliqua. Plant Cell, Tissue and Organ Culture. 68:35-41

Saïdi R, El bouzdoudi B, El Kbiach MB, Maouni A, Badoc A, Lamarti A. (2016) Micropropagation of Carob tree (Ceratonia siliqua L.) by cotyledonary buds. J. Mater. Environ. Sci. 7 (12): 4850-4859

Sayd SS, Abd El Shakour ZT (2014) Phenolic Content and Related Antioxidant Activities in in vitro Cultures of Cephalotaxus Harringtonia L. Grown in Egypt. Life Sci. J. 11(11):990-996
Shiga T, Shoji K, Shimada H, Hashida S, Goto F, Yoshihara T (2009) Effect of light quality on rosmarinic acid content and antioxidant activity of sweet basil. Ocimumba silicum L, Plant biotechnology 26:255-259

Sidina M, El Hansali M, Wahid N, Ouatmane A, Boulli A, Haddioui A (2009) Fruit and seed diversity of domesticated carob (Ceratonia siliqua L.) in Morocco. Scientia Horticulturae 123:110-116

Smith H (1982) Light quality, photoperception, and plant strategy.Annu: Rev. Plant Physiol. 33:481-518

Smith H (1994) Sensing the light environment: the functions of the phytochrome family. In: Kendrick RE, Kronenberg GHM (eds) Photomorphogenesis in Plants, 2nd edn. Kluwer Academic Publishers

Steel RGD, Torrie JH (1980) Principle of statistics. A biometrical approach. Second Ed, Mc Graw-Hill Kogakusha, L. T. D.

Szopa A, Ekiert H (2016) The importance of applied light quality on the production of lignins and phenolic acids in Schisandra chinensis (Turcz.) Baill. cultures in vitro. Plant Cell Tiss. Organ. Cult. 127:115-121

Thomas V, Metha AR (1983) Effect of phloroglucinol on shoot growth and initiation of roots in carob tree cultures grown in vitro. In Sen, S. K. and Giles, K. L. (eds). Proc. International Plant Cell Culture in Crop Improvement, Calcutta, India. Plenum Press, New York and London. 451-457

Thwe AA, Kim YB, Li X, Seo JM, Kim SJ, Suzuki T, Chung SO, Park SU (2014) Effects of light-emitting diodes on expression of phenylpropanoid biosynthetic genes and accumulation of phenylpropanoids in Fagopyrum tataricum sprouts. J. Agric. Food Chem. 62:4839-4845

Velioglu Y, Mazza G, Gao L, Oomah B (1998) Antioxidant activity and total phenolics in selected fruits, vegetables, and grain products. Journal of agricultural and food chemistry 46:4113-4117

Witomska M, Koszewska A (2002) Wpływjakościświatłai Cytokinin naorganogenezę in vitro petuniio grodowej (Petunia hybridaVlim.) Zeszyty Problemowe Postępów Nauk Rolniczych. 483: 271-280.

Younas M, Drouet S, Nadeem M, Giglioli-Guivarc'h N, Hano C, Abbasi BH (2018) Differential accumulation of silymarin induced by exposure of Silybummarianum $\mathrm{L}$. callus cultures to several spectres of monochromatic lights.Journal of Photochemistry \& Photobiology. B: Biology. 184:61-70

\section{Publisher's Note}

Springer Nature remains neutral with regard to jurisdictional claims in published maps and institutional affiliations.

\section{Submit your manuscript to a SpringerOpen ${ }^{\circ}$ journal and benefit from:}

- Convenient online submission

- Rigorous peer review

- Open access: articles freely available online

- High visibility within the field

- Retaining the copyright to your article

Submit your next manuscript at $\boldsymbol{\nabla}$ springeropen.com 